\title{
Unexplored Bacterial Diversity of Rajapur-Unhale Hot Spring, Ratnagiri District, Maharastra, India- A Gold Standard and MALDI-TOF Based Approach
}

\author{
Rajendran Mathan $\operatorname{Kumar}^{1 *}$, Suresh S S Raja ${ }^{1 \#}$ \\ ${ }^{1}$ Bharathidasan University Constituent College, Perambalur, TamilNadu. \\ ${ }^{1}$ * First author, ${ }^{1 \#}$ Corresponding author \\ E.Mail: kmathan2388@gmail.com ${ }^{1 *}$; sudalaimuthuraja@yahoo.co.in ${ }^{\text {I\# }}$
}

\begin{abstract}
In our study sediment and water samples was collected from the Rajapur-Unhale hot spring having $42{ }^{\circ} \mathrm{C}$ temperature. This study aimed to explore the unexplored bacterial diversity within the Rajapur-Unhale hotsprings. Fifty five isolates were obtained from both sediment and water samples were subjected to MALDI-TOF identification, were able to identify 15 isolates and most of the isolates which was not identified by direct cell loading method but was identified using ethanol/ formic acid extraction method and others gave not reliable identification with both the methods. For identification of bacterial species and genera, the sequencing centered on $16 \mathrm{~S}$ rRNA is most extensively used and accepted to categorize them phylogenetically. Whereas, 16S rRNA gene sequencing based identification could able to identify all the 55 isolates. This study shows the clear picture that the MALDI-TOF database needs to be updated with environmental isolates for effective and appropriate identification.
\end{abstract}

Keywords: Hot spring, 16S rRNA gene sequencing and MALDI-TOF

\section{INTRODUCTION}

The microbial biosphere is the major unexplored reservoir of biodiversity on the earth, and is an important forward-facing in ecology under exploration. Microbial diversity encompasses inquiry of microorganisms in relation to their biotic and abiotic environments. The enormous arrangement of microbial activities and their importance to the biosphere and to human economics provide strong rationale for understanding their diversity, conservation and exploitation. This is done with a variety of approaches and tools, including microscopy, culturing, biochemistry and molecular biology. The microorganisms are the living bodies which have ability to survive under extreme environmental conditions in which other organism are unable to survive. Microorganisms, in detail bacteria, continue to be revealed living under extreme ecological conditions such as low $\mathrm{pH}$, high and low temperature, high salinity etc. Thermophilic bacteria, a group of extremophiles whose optimal temperature for the growth lies between $42-80^{\circ} \mathrm{C}$, temperature goes beyond $80^{\circ} \mathrm{C}$ are called hyper-thermophiles. The bacteria can able to survive at very high temperature conditions such as hot springs, geysers, volcano etc. The ability of the bacterial enzymes and proteins which is produced from the extremophiles controls the specific metabolic and biological functions to be highly active at high temperature makes survival of these microorganisms in adverse conditions. In addition, cultivation of thermophiles at high temperature is technically and economically advantageous as it diminishes risk of contamination and viscosity which leads to high degree of substrate solubility.

Maharastra being rich in bio-diversity due to climatic differences owns a variety of hot-springs located in poles apart geographical locations and vary both in physio-chemical and microbial ecosystem parameters. In general, the temperature of rocks within the earth increases with depth. The rate of temperature increase with depth is known as the "geothermal gradient". A spring of naturally hot water, typically heated by subterranean volcanic activity and the water issuing from a hot spring is heated by geothermal heat, essentially heat from the Earth's interior. Geothermal energy is the heat from the Earth. Resources of geothermal energy range from the shallow ground to hot water and hot rock found a few miles beneath the Earth's surface, and down even deeper to the extremely high temperatures of molten rock called magma.

In Maharastra, several hot springs distributed in different regions having temperature ranges between 42 and $71^{\circ} \mathrm{C}$ have been known by geologists for many years, geographical distribution, chemical and physical characteristics of these springs were described by many researchers whereas few hot springs from this region was not completely explored. In our study sediment and water samples of Rajapur-Unhale hot spring with the latitude $16^{0} 38.7458^{\prime \prime} \mathrm{N}$ and longitude $73^{0} 31.8680^{\prime} \mathrm{E}$ was 


\section{Available online at www.ijrat.org}

collected from the hot spring having $42{ }^{\circ} \mathrm{C}$ temperature. This study aimed to explore the unexplored bacterial diversity within the RajapurUnhale hotsprings.

\section{MATERIALS AND METHODS:} 2.1. Study area and sample collection:
Sediment and water samples of hot springs of Rajapur-unhale were collected in April 2016. The temperature and $\mathrm{pH}$ of sediment and water was recorded at the site. The samples were collected in presterilized polypropylene bottles were placed in ice bags and transported in laboratory within $24 \mathrm{~h}$ (Table $1)$.

Table 1: Sampling location and Physical parameter of the hot spring

\begin{tabular}{|c|c|c|c|c|c|c|c|}
\hline \multirow[t]{2}{*}{ Sub-district } & \multirow[t]{2}{*}{ Hot spring } & \multicolumn{2}{|l|}{ Coordinates } & \multirow[t]{2}{*}{$\mathrm{pH}$} & \multirow{2}{*}{$\begin{array}{l}\text { Sampling } \\
\text { maximum depth } \\
\text { in feet } \\
\text { measurements }\end{array}$} & \multicolumn{2}{|c|}{ Temperature $\left.{ }^{0} \mathrm{C}\right)$} \\
\hline & & Latitude & Longitude & & & Observed & Reported \\
\hline Rajapur & $\begin{array}{l}\text { Unhale } \\
\text { (RS) }\end{array}$ & $\begin{array}{l}16^{0} 38.7458 \\
{ }^{\prime} \mathrm{N}\end{array}$ & $\begin{array}{l}73^{0} 31.8680 \\
{ }^{\prime} \mathrm{E}\end{array}$ & 7.5 & 1.8 & 42 & 42 \\
\hline
\end{tabular}

2.2. Media composition, serial dilution and plating:

A total of 8 different medium were used out of which seven were purchased from Himedia, India and the one were prepared to mimic the natural niche composition. In the process of preparation of the media hot spring water was taken and filtered with 0.4 micron filter paper to remove the bacterial contamination and then $2 \%$ of agar was mixed with it and given for autoclave. Both concentrated and diluted medium was used to isolate maximum bacterial colonies from the given consortium. The list of the medium used with their components and dilutions are provided herewith (Table 2)

\begin{tabular}{|c|c|c|c|}
\hline S.No & Medium & Components & gm/L \\
\hline 1 & Minimal medium & $\begin{array}{l}\left(\mathrm{NH}_{4}\right)_{2} \mathrm{SO}_{4} \\
\mathrm{~K}_{2} \mathrm{HPO}_{4} \\
\mathrm{MgSO}_{4} \cdot 7 \mathrm{H}_{2} \mathrm{O} \\
\mathrm{KCl} \\
\mathrm{Ca}\left(\mathrm{NO}_{3}\right)_{2} \cdot 4 \mathrm{H}_{2} \mathrm{O} \\
\text { Trace elements } \\
\mathrm{FeCl}_{3} \cdot 6 \mathrm{H}_{2} \mathrm{O} \\
\mathrm{CuSO}_{4} \cdot 5 \mathrm{H}_{2} \mathrm{O} \\
\mathrm{H}_{3} \mathrm{BO}_{3} \\
\mathrm{MnSO}_{4} \cdot \mathrm{H}_{2} \mathrm{O} \\
\mathrm{Na}_{2} \mathrm{MoO}_{4} \cdot 2 \mathrm{H}_{2} \mathrm{O} \\
\mathrm{CoCl}_{2} \cdot 6 \mathrm{H}_{2} \mathrm{O} \\
\mathrm{ZnSO}_{4} \cdot 7 \mathrm{H}_{2} \mathrm{O}\end{array}$ & $\begin{array}{l}3 \\
0.5 \\
0.5 \\
0.1 \\
0.01 \\
\mathbf{1 m l} \\
1.1 \\
0.05 \\
0.2 \\
0.2 \\
0.08 \\
0.06 \\
0.09\end{array}$ \\
\hline 2 & $\begin{array}{l}\text { Reasoner's } 2 \mathrm{~A} \text { agar }(\mathrm{R} 2 \mathrm{~A}) \\
\text { Without dilution and } \\
\text { dilutions }\end{array}$ & $\begin{array}{l}\text { Casein acid hydrolysate } \\
\text { Yeast extract } \\
\text { Proteose peptone } \\
\text { Dextrose } \\
\text { Starch, soluble } \\
\text { Dipotassium phosphate } \\
\text { Magnesium sulphate } \\
\text { Sodium pyruvate } \\
\text { Agar }\end{array}$ & $\begin{array}{l}0.5 \\
0.5 \\
0.5 \\
0.5 \\
0.5 \\
0.3 \\
0.024 \\
0.3 \\
15\end{array}$ \\
\hline 3 & $\begin{array}{l}\text { Tryptic Soy Agar (TSA) } \\
\begin{array}{l}\text { Without dilution and } \\
\text { dilutions }\end{array}\end{array}$ & $\begin{array}{ll}\text { Pancreatic digest } & \text { of } \\
\text { casein } & \\
\text { Papaic digest } & \text { of } \\
\text { soyabean meal } & \\
\text { Sodium chloride } & \\
\text { Agar } & \end{array}$ & $\begin{array}{l}15 \\
5 \\
5 \\
15\end{array}$ \\
\hline 4 & $\begin{array}{l}\text { Luria-Bertani (LB) Agar } \\
\text { Without dilution and } 1: 100 \\
\text { dilutions }\end{array}$ & $\begin{array}{ll}\text { Casein } & \text { enzymic } \\
\text { hydrolysate } & \\
\text { Yeast extract } & \end{array}$ & $\begin{array}{l}10 \\
5 \\
10\end{array}$ \\
\hline
\end{tabular}




\section{Available online at www.ijrat.org}

\begin{tabular}{|c|c|c|c|}
\hline & & $\begin{array}{l}\text { Sodium chloride } \\
\text { Agar }\end{array}$ & 15 \\
\hline 5 & $\begin{array}{l}\text { Nutrient Agar (NA) } \\
\text { Without dilution and } 1: 100 \\
\text { dilutions }\end{array}$ & $\begin{array}{l}\text { Peptic digest of animal } \\
\text { tissue } \\
\text { Sodium chloride } \\
\text { Beef extract } \\
\text { Yeast extract } \\
\text { Agar }\end{array}$ & $\begin{array}{l}5 \\
5 \\
1 \\
1 \\
15\end{array}$ \\
\hline 6 & $\begin{array}{l}\text { Actinomyces Isolation agar (AIA) } \\
\text { Without dilution and } 1: 100 \\
\text { dilutions }\end{array}$ & $\begin{array}{l}\text { Sodium caseinate } \\
\text { L-Asparagine } \\
\text { Sodium propionate } \\
\text { Dipotassium phosphate } \\
\text { Magnesium sulphate } \\
\text { Ferrous sulphate } \\
\text { Agar }\end{array}$ & $\begin{array}{l}2 \\
0.1 \\
4 \\
0.5 \\
0.1 \\
0.001 \\
15 \\
\end{array}$ \\
\hline 7 & Tryptone Yeast Extract Agar & $\begin{array}{l}\text { Casein enzymic } \\
\text { hydrolysate } \\
\text { Yeast extract powder } \\
\text { Agar }\end{array}$ & $\begin{array}{l}6 \\
3 \\
15\end{array}$ \\
\hline 8 & Hot-water spring agar & $\begin{array}{l}\text { Hot spring water (From } \\
\text { each niche) } \\
\text { Agar } \\
\text { Filter the hot-spring } \\
\text { water, add agar and then } \\
\text { autoclave it }\end{array}$ & $\begin{array}{l}1 \mathrm{~L} \\
15\end{array}$ \\
\hline
\end{tabular}

Both sediment and water were suspended in normal saline $(0.85 \%)$ and serially diluted. The serially diluted samples were plated on the respective agar mediums listed above followed by incubation at the natural niche temperature. CFU was recorded for each samples against each media composition used.

\subsection{DNA isolation}

The isolates were subjected to DNA isolation (Mayilraj et al, 2006) using ZymoResearch kit based method in which it contains lysis buffer to lyse the bacterial cells by adding $500 \mu 1$ and then vortexes for 5 mins to disrupt the bacterial cells, centrifuge for 2 mins at $10000 \mathrm{rpm}$. Collect the supernatant and add $12000 \mu 1$ of binding buffer to bind the reagents with bacterial DNA and separates it. Add $600 \mu l$ of the solution into the spin column and centrifuge at 10000rpm for 2 mins. Discard the flow through and save the column, add $500 \mu \mathrm{l}$ of DNA pre wash buffer into the column and centrifuge at $10000 \mathrm{rpm}$ for 2 mins. Discard the flow through and add DNA wash buffer $500 \mu 1$, centrifuge at $10000 \mathrm{rpm}$ for $2 \mathrm{mins}$ and discard the flow through. Empty spin the column to remove the extra buffer which hinders or interferes the DNA. Add elution buffer directly into the column with the filter that can elute the DNA. The eluted DNA can be stored in to a fresh tube for further experiments and checked for their quality by gel electrophoresis $(0.8 \%$ agarose $)$ at $100 \mathrm{~V}$ for $10-15$ $\min$.

\subsection{PCR amplification and sequencing of the $16 S$} rDNA

The 16S rRNA gene was amplified by the method in which the primers 8-27f (5'AGAGTTTGATCCTGGCTCAG-3') and 1492r (5'AGAAAGGAGGTGATCCAGGC-3') were used [9]. The PCR program was set up as follows: initial incubation at $94^{\circ} \mathrm{C}$ for $5 \mathrm{~min}$ followed by 35 cycles $\left(94^{\circ} \mathrm{C}\right.$ for $1 \mathrm{~min}, 52.5^{\circ} \mathrm{C}$ for $1 \mathrm{~min}$ and $72^{\circ} \mathrm{C}$ for 2 min) and final extension at $72^{\circ} \mathrm{C}$ for 10 min using thermal cycler. The amplified DNA fragment was separated on $1 \%$ agarose gel eluted from the gel and purified using Macherey-Nagel PCR/Gelpurification kit (Macherey-Nagel, Germany). The purified PCR product was sequenced with forward and reverse primers namely 8-27f (5'AGAGTTTGATCCTGGCTCAG-3'), 357f (5'CTCCTACGGGAGGCAGCAG-3') and518r (5'ATTACCGCGGCTGCTGG-3'), 1100r (5'GGGTTGCGCTCGTTG-3'), 1492r (5'GGTTACCTTGTTACGACTT-3'), respectively (Escherichia coli numbering system) (Kumar et al, 2015) (table 3).

\begin{tabular}{|l|l|}
\hline Table 3. PCR set up for16S rRNA gene amplication \\
\hline Thermo pol buffer $(10 \mathrm{X})$ & $5 \mu \mathrm{l}$ \\
\hline
\end{tabular}


International Journal of Research in Advent Technology, Vol.7, No.4, April 2019

E-ISSN: 2321-9637

Available online at www.ijrat.org

\begin{tabular}{|l|l|}
\hline Genomic DNA & $100-200 \mathrm{ng}$ \\
\hline Forward primer & $2 \mu \mathrm{M}$ \\
\hline Reverse primer & $2 \mu \mathrm{M}$ \\
\hline dNTPs & $800 \mu \mathrm{M}$ \\
\hline Taq Polymerase & $1 \mathrm{U} / 50 \mu \mathrm{l}$ \\
\hline
\end{tabular}

\subsection{PEG- Nacl (polyethylene glycol) purification of PCR amplified products}

Polyethylene glycol (PEG), used for precipitation of DNA. In this process a solution containing salt and PEG were added to an aqueous nucleic acid sample, which was then incubated. This results in precipitation of nucleic acids, which were then precipitated by centrifugation and then washed twice in $70 \%$ ethanol.

PEG- Nacl purification was done to precipitate the PCR product, removing the primer dimer and other reaction mixture. The steps followed were as stated below; 0.6 volumes of $20 \%$ PEG-Nacl were added to the final volume of the PCR product. It was followed by incubation at $37^{\circ} \mathrm{C}$ for 20 minutes. Centrifuge at 12000rpm for 30 minutes, Decant/if plate Invert spin up to $400 \mathrm{rpm}$. $50 \mu \mathrm{l}$ of the $70 \%$ ethanol was added to wash the pellet. Centrifugation was done at 12,000 (tube)/3800 (plate) rpm for 30 minutes.Supernatant was decanted/Invert spin at 400rpm for 5-10seconds. Air dry and then 10-20 $\mu \mathrm{l}$ of the distilled water was added to the tubes and the purified products were checked on $1 \%$ agarose gel electrophoresis.

\subsection{Sequencing of $16 S \mathrm{rDNA}$}

Sequencing of the purified PCR product $(\sim 200$ ng/reaction) was carried out using 2 pmoles of a given sequencing primer and $4 \mu 1$ of ready reaction The rDNA sequence was determined by the dideoxy chain-termination method using the Big - Dye terminator kit using ABI 3130xl Genetic Analyzer (Applied Biosystems, USA) mix from the Big Dye Terminator sequencing kit (ABI) in a total volume of $10 \mu 1$. Cycle sequencing was carried out in a PCR machine (Eppendorf-Gradient) for 30 cycles. Initial incubation at $96^{\circ} \mathrm{C}$ for $1 \mathrm{~min}$ followed by 25 cycles of sequencing and each cycle consisted of a denaturation step at $96^{\circ} \mathrm{C}$ for $10 \mathrm{~s}$, an annealing step at $50^{\circ} \mathrm{C}$ for $10 \mathrm{~s}$ and an extension step at $60^{\circ} \mathrm{C}$ for 4 min. After the PCR, the products were precipitated using $1 \mu \mathrm{l}$ of $3 \mathrm{M}$ sodium acetate ( $\mathrm{pH} 4.6$ ) and $50 \mu \mathrm{l}$ of ethanol and incubated on ice for $15 \mathrm{~min}$. The pellet was recovered by centrifugation at $15000 \mathrm{rpm}$ for 20 min at $4^{\circ} \mathrm{C}$, washed with $70 \%$ ethanol, dried under vacuum and dissolved in $10 \mu 11$ of loading buffer [formamide: $25 \mathrm{mM}$ EDTA (4:1)]. About $2 \mu \mathrm{l}$ of the sample was used to analyze the sequence and the rDNA sequence was determined by the dideoxy chain-termination method using the Big - Dye terminator kit using ABI 3130xl Genetic Analyzer (Applied Biosystems, USA) (table 4). The purified DNA was used for sequencing of either partial or full 16S rDNA.

\begin{tabular}{|l|l|}
\hline Table 4. PCR reaction mixture for sequencing \\
\hline DNA & $50 \mathrm{ng}$ \\
\hline Sequencing buffer (5X) & $1.5 \mu \mathrm{l}$ \\
\hline Primer (forward or reverse) & 2 picomoles \\
\hline Terminator ready raction (TRR) mix & $1 \mu \mathrm{l}$ \\
\hline
\end{tabular}

\subsection{S rRNA gene sequence analysis}

The identification of phylogenetic neighbors and the calculation of pairwise 16S rRNA gene sequence similarities were achieved using the EzTaxon server (http://www.ezbiocloud.net/eztaxon; Kim et al, 2012). The 16S rRNA gene sequence of hot spring sediment and water sample isolates were aligned using the MEGA software version 6.0 (Tamura et al, 2013). Phylogenetic trees were constructed using the Neighbor-joining algorithm (Saitou \& Nei 1987). Bootstrap analysis was performed to assess the confidence limits of the branching (Felsenstein, 1981; Felsenstein,1985).

\subsection{Sample preparation for MALDI analysis}

Sample preparation was done with some modifications to the manufacturer's method which are as mentioned below:

\subsubsection{Direct Transfer Method}

Bacterial culture was homogenously smeared as a thin film directly onto a cleaned MALDI target plate or grids. Each sample position was overlaid with $1 \mu \mathrm{l}$ matrix solution. The sample was allowed to dry at room temperature. The sample was inserted into the MALDI-TOF mass spectrometer (Bruker Daltonik, Bremen, Germany) for analysis.

\subsubsection{Protein Extraction Method}

At first $300 \mu \mathrm{l}$ of ultra-pure water was pipetted into a clean Eppendorf tube. 5-10 mg of biological material 


\section{Available online at www.ijrat.org}

was transferred into the tube and vortexed to form a homogenous suspension. $900 \mu \mathrm{l}$ of pure ethanol was added into the tube and vortexed for at least 1 minute. The tube was centrifuged for 2 minutes at 13,000 rpm and the supernatant was discarded. $50 \mu \mathrm{l}$ of $70 \%$ formic acid was added into the Eppendorf tube and was vortexed. An equal volume of $100 \%$ acetonitrile was added to the tube and mixed carefully. $1 \mu \mathrm{l}$ of cell suspension was plated on the target overlaid with $1 \mu \mathrm{l}$ of matrix. The sample was allowed to dry at room temperature and inserted into the MALDI-TOF mass spectrometer. The cell suspension was centrifuged for 2 minutes at $13,000 \mathrm{rpm}$. $1 \mu \mathrm{l}$ of extract supernatant was pipetted onto a cleaned MALDI target. The sample was allowed to dry at room temperature. The sample was overlaid with $1 \mu \mathrm{l}$ matrix, dried and inserted into MALDI-TOF mass spectrometer for analysis.

\subsection{MALDI-TOF MS analysis}

For the analysation of MALDI-TOF mass spectra obtained from Ultraflex III instrument operated in linear positive mode under FlexControl 3.1 software. External calibration of the mass spectra was done using Escherichia coli DH5 alpha standard peaks (4346.3, 5095.8, 5380.4, 6254.4, 7273.5 and 10,299.1 Da). Laser power was set to $120 \%$ of the threshold laser power was used for the sample. Five independent spectra comprising 240 laser shots were acquired from each spot. Within an individual spot, the laser was manually directed when required in addition to a pre-defined lattice raster. Mass spectra were processed using Flex Analysis (version 3.1; Bruker Daltonik) and BioTyper software (version 3.1; Bruker Daltonik).

\section{RESULTS AND DISCUSSION \\ 3.1. Serial Dilution, Plating And Purification of The Isolates}

The serially diluted sediment and water samples were plated (Table 5) in a respective medium and incubated at natural niche temperature at $42^{\circ} \mathrm{C}$ for 2 weeks (Fig.1). Colonies were observed after 5 days of incubation. Among the sediment and water samples, the sediment sample showed more isolates than water samples. The isolates obtained from the spread plating were then patch streaked and incubated at respective temperature (Fig.2). The samples comprising both pigmented and nonpigmented colonies were observed and patch streaked. The patch streaked isolates were purified and preserved in $-80{ }^{\mathrm{O}} \mathrm{C}$ for further experiments (Fig.3). In Rajapur-Unhale sediment, 40 isolates were obtained and 15 isolates were obtained from RajapurUnhale water sample.

\begin{tabular}{|l|ll|l|l|l|l|l|l|l|}
\hline \multicolumn{2}{|c|}{ Table 5: Serial dilution of hot spring sediment and water samples } \\
\hline 1 & $\begin{array}{l}\text { Rajapur-Unhale hot } \\
\text { spring sediment }\end{array}$ & $10^{0}$ & $10^{-1}$ & $10^{-2}$ & $10^{-3}$ & $10^{-4}$ & $10^{-5}$ & $10^{-6}$ \\
\hline 2 & $\begin{array}{l}\text { Rajapur-Unhale hot } \\
\text { spring water }\end{array}$ & $10^{0}$ & $10^{-1}$ & $10^{-2}$ & $10^{-3}$ & $10^{-4}$ & $10^{-5}$ & $10^{-6}$ \\
\hline
\end{tabular}

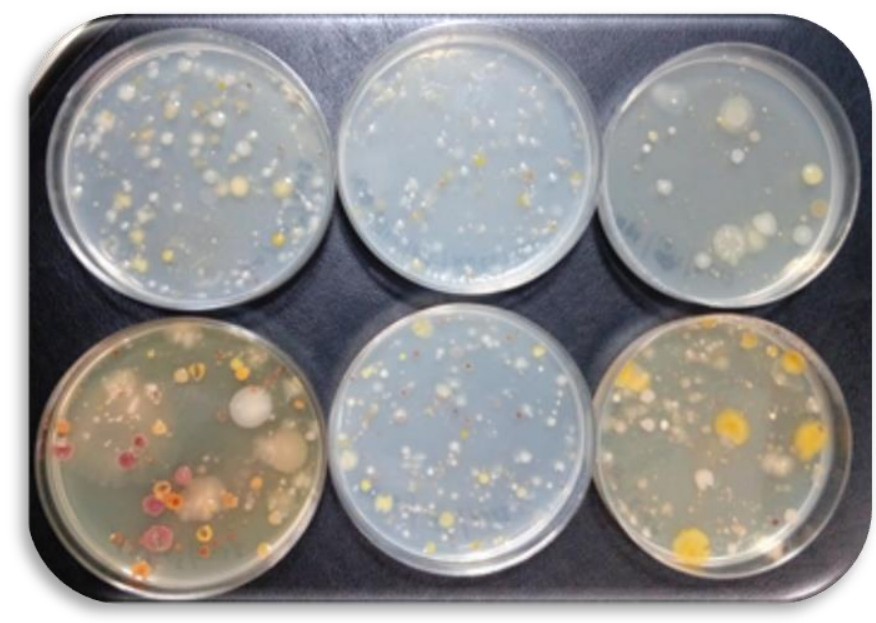

Fig.1. Spread plating of hot spring sediment and water 


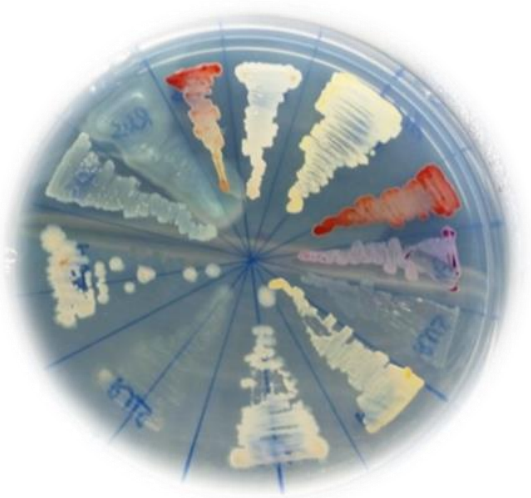

Fig.2. Patch streaking of the individual isolates 3.2. MALDI-TOF Identification

One sixty six isolates were subjected to MALDI-TOF based identification. MALDI-TOF mass spectra were obtained from an ultraflex III instrument operated in linear positive mode under flex-Control 3.1 software. External calibration of the mass spectra was done using standard peaks from E. coli DH5 $\alpha$ (4346.3, 5095.8, 5380.4, 6254.4, 7273.5 and $10299.1 \mathrm{da}$ ). Laser power was set to $120 \%$ of the threshold laser power. This software generates classification models from large numbers of spectra and detects small differences among different clusters, based on mass, signal-to-noise, intensity, peak heights and peak areas. Among 55 isolates obtained only 15 isolates were identified as Kocuria palustris, Staphylococcus hominis, Bacillus cereus, Pseudomonas alcaligenes, Enterobacter kobei, Aeromonas veronii, Escherichia coli, Staphylococcus capitis, Micrococcus luteus, Pseudomonas mendocina and Enterobacter ludwigii were taken into consideration which showed above $2 \%$ cut-off value by MALDI-TOF and rest of the isolates failed in identification through MALDI-TOF based approach

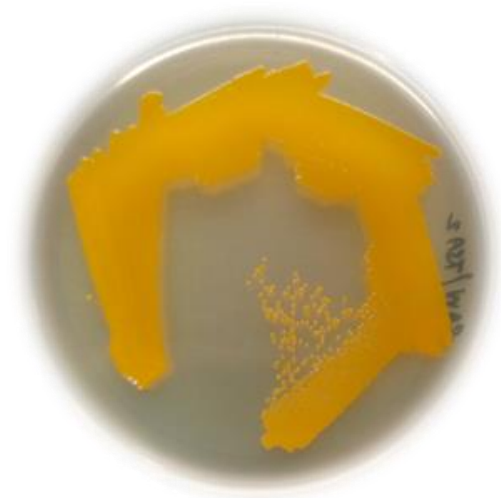

Fig.3. Purification of isolates

Few isolates from Rajapur water and sediments samples were identified in MALDI-TOF identification. Two methods of MALDI identification of 55 isolates were done using 1) Ethanol/ formic acid extract and 2) direct cell loading. In Direct Method of identification the isolates RS9, RS17, RS19, RS41, RS53, RW8, RW12, RW17 and RW18 were identified. Whereas, in ethanol/ formic acid extraction method the isolates RS2, RS9, RS17, RS19, RS22, RS23, RW5, RW7, RW8, RW12, RW17 and RW18 were identified. Both the methods were able to identify 15 isolates and most of the isolates which was not identified by direct cell loading method (table 6) but was identified using ethanol/ formic acid extraction method (table 7) and others gave not reliable identification with both the methods. This shows the clear picture that the necessity of MALDI-TOF database to be updated with the large number of environmental bacterial isolates. Further the isolates were subjected to DNA isolation for the 16S rRNA gene sequence based identification to know the exact/ proper identification of the hot spring isolates.

\begin{tabular}{|c|c|c|c|c|}
\hline Strain ID & Organism identified & Cut off value & Organism identified & Cut off value \\
\hline MKAS - RS2 & no peaks found & $<0$ & no peaks found & $\leq 0$ \\
\hline MKAS - RS9 & Enterobacter kobei & 2.067 & Enterobacter cloacae & 1.862 \\
\hline MKAS - RS17 & Escherichia coli & 2.297 & Escherichia coli & 2.194 \\
\hline MKAS - RS19 & Staphylococcus capitis & $\underline{1.715}$ & $\begin{array}{ll}\text { not } & \text { reliable } \\
\text { identification } & \end{array}$ & 1.655 \\
\hline MKAS - RS22 & $\begin{array}{ll}\text { not } & \text { reliable } \\
\text { identification } & \end{array}$ & 1.528 & $\begin{array}{ll}\text { not } & \text { reliable } \\
\text { identification } & \end{array}$ & 1.505 \\
\hline MKAS - RS23 & $\begin{array}{ll}\text { not } & \text { reliable } \\
\text { identification } & \\
\end{array}$ & $\underline{1.524}$ & $\begin{array}{ll}\text { not } & \text { reliable } \\
\text { identification } & \\
\end{array}$ & 1.475 \\
\hline MKAS - RS41 & Pseudomonas alcaligenes & $\underline{1.849}$ & $\begin{array}{ll}\text { not } & \text { reliable } \\
\text { identification } & \\
\end{array}$ & $\underline{1.645}$ \\
\hline MKAS - RS53 & $\underline{\text { Bacillus subtilis }}$ & $\underline{1.825}$ & $\underline{\text { Bacillus subtilis }}$ & $\underline{1.803}$ \\
\hline MKAS - RW5 & $\begin{array}{ll}\text { not } & \text { reliable } \\
\text { identification }\end{array}$ & 1583 & $\begin{array}{ll}\text { not } & \text { reliable } \\
\text { identification }\end{array}$ & 15 \\
\hline
\end{tabular}


International Journal of Research in Advent Technology, Vol.7, No.4, April 2019

E-ISSN: 2321-9637

Available online at www.ijrat.org

\begin{tabular}{|l|l|l|l|l|} 
MKAS - RW7 & no peaks found & $\leq 0$ & no peaks found & $\leq 0$ \\
\hline MKAS - RW8 & Staphylococcus hominis & $\underline{2.233}$ & Staphylococcus hominis & $\underline{2.011}$ \\
\hline MKAS - RW9 & $\begin{array}{l}\text { not reliable } \\
\text { identification }\end{array}$ & $\underline{1.373}$ & $\begin{array}{l}\text { not reliable } \\
\text { identification }\end{array}$ & $\underline{1.305}$ \\
\hline MKAS - RW12 & Bacillus sp. & $\underline{1.897}$ & $\underline{\text { Bacillus subtilis }}$ & $\underline{1.83}$ \\
\hline MKAS - RW17 & Enterobacter hormaechei & $\underline{2.134}$ & Enterobacter cloacae & $\underline{2.127}$ \\
\hline MKAS - RW18 & Pseudomonas alcaligenes & $\underline{2.331}$ & Pseudomonas alcaligenes & $\underline{2.258}$ \\
\hline
\end{tabular}

\begin{tabular}{|l|l|l|l|l|}
\hline \multicolumn{6}{|l|}{ Table 7. MALDI-TOF based identification by Ethanol: formic acid extraction method } \\
\hline Strain ID & Organism identified & Cut off value & Organism identified & Cut off value \\
\hline MKAS - RS2 & $\begin{array}{l}\text { Corynebacterium } \\
\text { mucifaciens }\end{array}$ & $\underline{1.976}$ & $\begin{array}{l}\text { Corynebacterium } \\
\text { mucifaciens }\end{array}$ & $\underline{2.146}$ \\
\hline MKAS - RS9 & Enterobacter kobei & $\underline{2.292}$ & $\underline{\text { Enterobacter asburiae }}$ & $\underline{2.115}$ \\
\hline MKAS - RS17 & Escherichia coli & $\underline{2.455}$ & $\underline{\text { Escherichia coli }}$ & $\underline{1.972}$ \\
\hline MKAS - RS19 & Staphylococcus capitis & $\underline{2.2}$ & Staphylococcus capitis & $\underline{1.519}$ \\
\hline MKAS - RS22 & Pseudomonas oleovorans & $\underline{1.934}$ & Pseudomonas oleovorans & $\underline{1.938}$ \\
\hline MKAS - RS23 & Micrococcus luteus & $\underline{2.078}$ & Micrococcus luteus & $\underline{1.403}$ \\
\hline MKAS - RS41 & no peaks found & $\leq \underline{0}$ & no peaks found & $\leq 0$ \\
\hline MKAS - RS53 & $\begin{array}{l}\text { not } \\
\text { identification }\end{array}$ & $\underline{1.825}$ & $\begin{array}{l}\text { not } \\
\text { identification }\end{array}$ & $\underline{1.803}$ \\
\hline MKAS - RW5 & Kocuria palustris & $\underline{2.119}$ & Kocuria palustris & $\underline{2.101}$ \\
\hline MKAS - RW7 & $\begin{array}{l}\text { Pseudomonas } \\
\text { alcaligenes }\end{array}$ & $\underline{2.214}$ & $\begin{array}{l}\text { Pseudomonas } \\
\text { alcaligenes }\end{array}$ & $\underline{2.151}$ \\
\hline MKAS - RW8 & Staphylococcus hominis & $\underline{2.233}$ & Staphylococcus hominis & $\underline{2.011}$ \\
\hline MKAS - RW9 & $\begin{array}{l}\text { Moraxella_sg_Moraxella } \\
\text { osloensis }\end{array}$ & $\underline{1.937}$ & $\begin{array}{l}\text { Moraxella_sg_Moraxella } \\
\text { osloensis }\end{array}$ & $\underline{1.805}$ \\
\hline MKAS - RW12 & Bacillus sp. & $\underline{1.897}$ & $\underline{\text { Bacillus subtilis }}$ & $\underline{1.83}$ \\
\hline MKAS - RW17 & Enterobacter cloacae & $\underline{2.258}$ & Enterobacter kobei & $\underline{2.128}$ \\
\hline MKAS - RW18 & Enterobacter cloacae & $\underline{2.193}$ & Enterobacter ludwigii & $\underline{2.161}$ \\
\hline
\end{tabular}

\subsection{DNA Isolation:}

DNA was successfully isolated from both sediment and water samples of Rajapur-Unhale hot spring. All the 55 isolates were subjected to DNA isolation, the concentration and purity of the samples were checked in Nano-Drop. The DNA of all the isolates were of good quantity and quality was confirmed in agarose gel electrophoresis with $0.8 \%$ agarose (fig.4). The quantification of isolated DNA further subjected to nanodrop in which the ratio of absorbance at $260 \mathrm{~nm}$ and $280 \mathrm{~nm}$ was used to assess the purity of DNA and RNA. A ratio of $\sim 1.8$ was generally accepted as "pure" for DNA; a ratio of $\sim 2.0$ was generally accepted as "pure" for RNA. If the ratio is appreciably lower in either case, it may indicate the presence of protein, phenol or other contaminants that absorb strongly at or near $280 \mathrm{~nm}$. The genomic DNA of the isolates were dissolved in TE or ultrapure water and stored at $-20^{\circ} \mathrm{C}$ for further experiments especially Polymerase chain reaction (PCR). 
International Journal of Research in Advent Technology, Vol.7, No.4, April 2019

E-ISSN: 2321-9637

Available online at www.ijrat.org

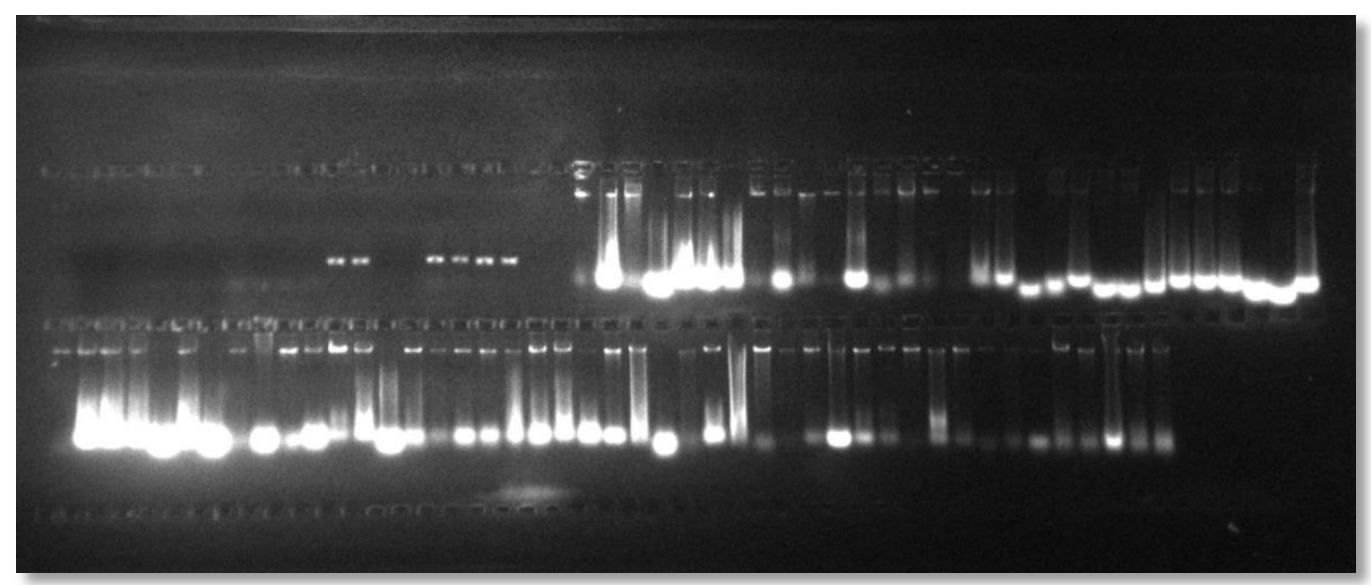

Fig.4. DNA isolation of the representative isolates

\subsection{S Rrna Gene Amplification}

The 16S rRNA was the gold standard method to identify the bacterial isolates. 16S rRNA genes were amplified using universal eubacterial primers $27 \mathrm{f}$ (59-AGAGTTTGATCCTGGCTCAG-39) and 1492r (59-AAGTCGTAACAAGGTAACCGTA-39). The amplified DNA fragment was confirmed in agarose gel electrophoresis with $1 \%$ agarose concentration and purified using PEG purification. The purified PCR product was sequenced with primers $27 \mathrm{f}, 357 \mathrm{f}$, 518r, 926f, 1100r and 1492r (Escherichia coli numbering system) shown in fig.5.

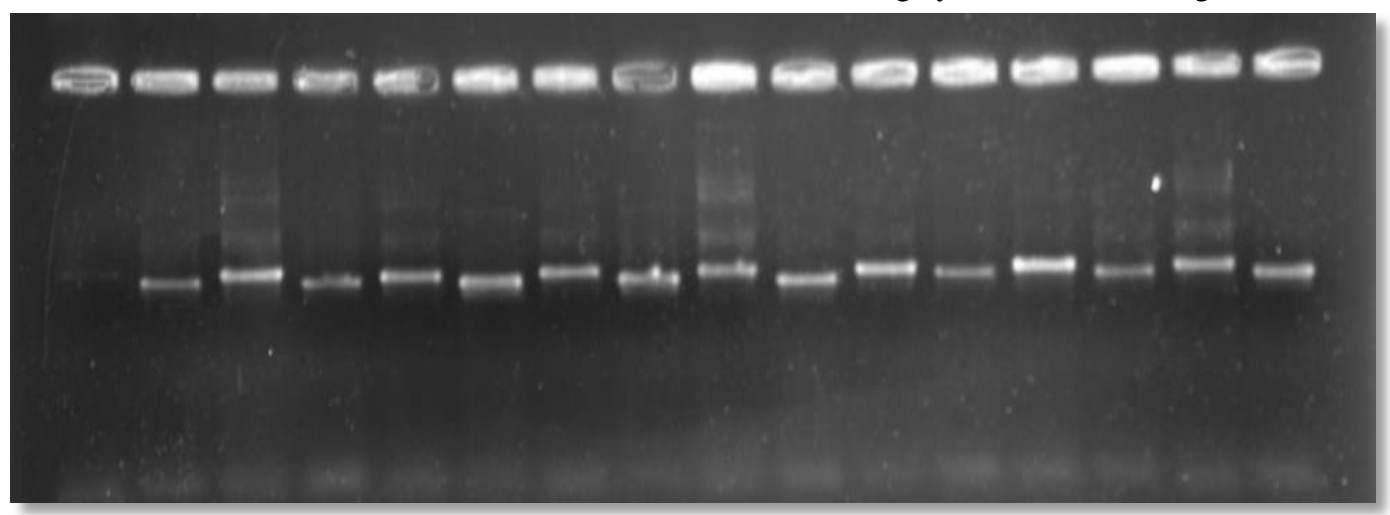

Fig.5. 16S rRNA gene amplification of the representative isolates from hotsprings

\subsection{PEG Purification Of PCR Product}

In this figure the bands signify the presence of amplified product. Those of which were not amplified were again processed for PCR amplification and then all the samples were processed for PEG purification.

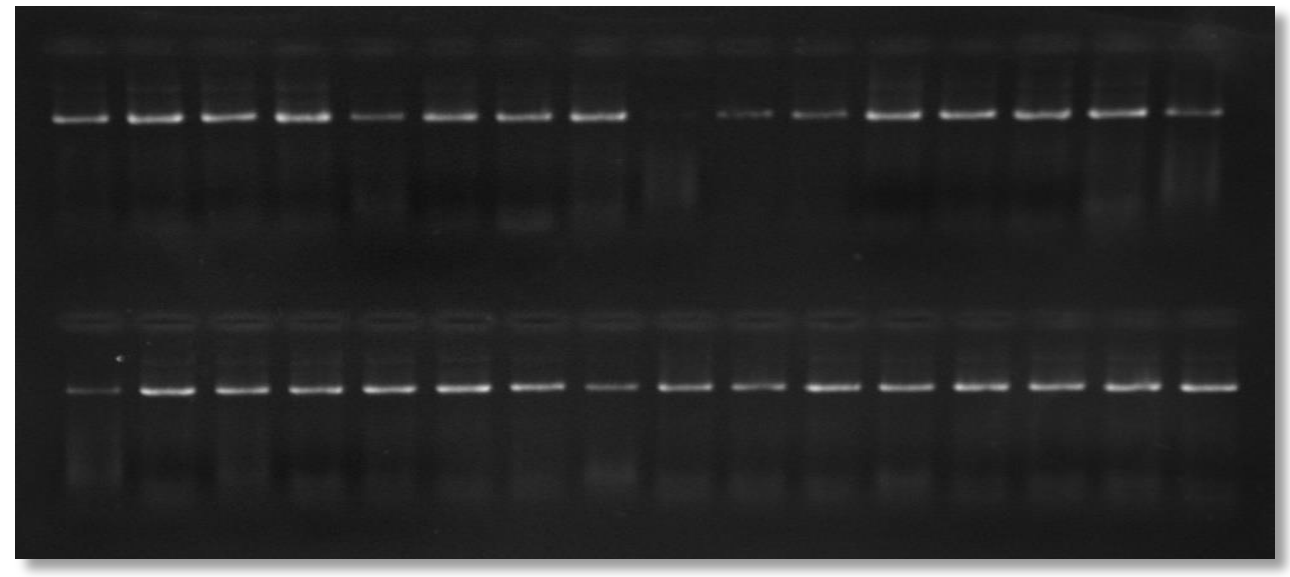




\section{Fig.6. PEG purification of $16 \mathrm{~S}$ rRNA gene amplification product of the representative isolates from hotsprings}

In this figure the bands signify the PEG purification of amplified product. Those of which were not purified were again processed for PCR amplification and then all the samples were further subjected to PEG purification. The purified products were further subjected to $16 \mathrm{~S}$ rRNA gene sequence which was determined by the dideoxy chain-termination method using the Big-Dye terminator kit with an ABI 310 Genetic Analyzer (Applied Biosystems).Samples showing PCR amplification, checked on $1 \%$ agarose gel is shown in the fig.6.

\subsection{Identification Of The Hot Spring Isolates}

The hotspring isolates were sequenced, assembled and identified through Ez-Taxon server by blast search analysis of the sequences in fasta format. Fifty five isolates were identified through 16S rRNA gene sequencing.
In Rajapur, unahale sediment samples, the isolates were identified as Aquaspirillum serpens, Azospira oryzae, Azovibrio restrictus, Bacillus murimartini, Bacillus tequilensis, Cloacibacterium normanense, Cloacibacterium rupense, Corynebacterium mucifaciens, Enterobacter tabaci, Flexibacter flexilis, Gordonia hongkongensis, Macellibacteroides fermentans, Microbacterium aurantiacum, Microbacterium barkeri, Microbacterium dextranolyticum, Microbacterium natoriense, Microbacterium saccharophilum, Micrococcus aloeverae, Ornithinimicrobium pekingense, Porphyrobacter colymbi, Pseudomonas composti, Pseudomonas oleovorans subsp. oleovorans, Rhodococcus kroppenstedtii, Staphylococcus capitis subsp. capitis, Xanthobacter flavus, Xanthobacter tagetidis and Zavarzinia compransoris were mentioned in table 8.

\begin{tabular}{|c|l|l|l|}
\hline \multicolumn{3}{|l|}{ Table 8. 16S rRNA gene sequencing of Rajapur-Unhale sediment sample } \\
\hline S.No & Strain id & 16S rRNA based identification & $\begin{array}{l}\text { Sequence } \\
\text { acession } \\
\text { numbers }\end{array}$ \\
\hline 1 & RS1 & Cloacibacterium normanense & MH715173 \\
\hline 2 & RS2 & Corynebacterium mucifaciens & MH715174 \\
\hline 3 & RS3 & Azovibrio restrictus & MH715175 \\
\hline 4 & RS4 & Microbacterium dextranolyticum & MH715176 \\
\hline 5 & RS5 & Flexibacter flexilis & MH715177 \\
\hline 6 & RS6 & Aquaspirillum serpens & MH715178 \\
\hline 7 & RS8 & Microbacterium aurantiacum & MH715179 \\
\hline 8 & RS9 & Enterobacter tabaci & MH715180 \\
\hline 9 & RS10 & Cloacibacterium normanense & MH715181 \\
\hline 10 & RS17 & Cloacibacterium normanense & MH715182 \\
\hline 11 & RS19 & Staphylococcus capitis subsp. capitis & MH715183 \\
\hline 12 & RS22 & $\begin{array}{l}\text { Pseudomonas } \\
\text { oleovorans }\end{array}$ & MH715184 \\
\hline 13 & RS23 & Bacillus murimartini & MH715185 \\
\hline 14 & RS26 & Azospira oryzae & MH715186 \\
\hline 15 & RS33 & Azospira oryzae & MH715187 \\
\hline 16 & RS34 & Enterobacter tabaci & MH715188 \\
\hline 17 & RS36 & Azovibrio restrictus & MH715189 \\
\hline 18 & RS37 & Micrococcus aloeverae & MH715190 \\
\hline 19 & RS38 & Porphyrobacter colymbi & MH715191 \\
\hline 20 & RS39 & Zavarzinia compransoris & MH715192 \\
\hline 21 & RS40 & Aquaspirillum serpens & MH715193 \\
\hline 22 & RS41 & Microbacterium barkeri & MH715194 \\
\hline 23 & RS42 & Ornithinimicrobium pekingense & MH715195 \\
\hline 24 & RS43 & Ornithinimicrobium pekingense & MH715196 \\
\hline 25 & RS44 & Rhodococcus kroppenstedtii & MH715197 \\
\hline 26 & RS46 & Gordonia hongkongensis & MH715199 \\
\hline 27 & RS47 & Microbacterium aurantiacum & \\
\hline & & & \\
\hline
\end{tabular}


International Journal of Research in Advent Technology, Vol.7, No.4, April 2019

E-ISSN: 2321-9637

Available online at www.ijrat.org

\begin{tabular}{|l|l|l|l|}
\hline 28 & RS48 & Zavarzinia compransoris & MH715200 \\
\hline 29 & RS51 & Cloacibacterium normanense & MH715201 \\
\hline 30 & RS53 & Bacillus tequilensis & MH715202 \\
\hline 31 & RS54 & Macellibacteroides fermentans & MH715203 \\
\hline 32 & RS55 & Cloacibacterium rupense & MH715204 \\
\hline 33 & RS56 & Azovibrio restrictus & MH715205 \\
\hline 34 & RS57 & Microbacterium natoriense & MH715206 \\
\hline 35 & RS58 & Microbacterium saccharophilum & MH715207 \\
\hline 36 & RS59 & Microbacterium saccharophilum & MH715208 \\
\hline 37 & RS60 & Xanthobacter flavus & MH715209 \\
\hline 38 & RS61 & Xanthobacter tagetidis & MH715210 \\
\hline 39 & RS62 & Azovibrio restrictus & MH715211 \\
\hline 40 & RS63 & Pseudomonas composti & MH715212 \\
\hline
\end{tabular}

In Rajapur, unahale water samples, the isolates were identified as Bacillus subtilis subsp. inaquosorum, Bacillus tequilensis, Elstera litoralis, Enhydrobacter aerosaccus, Enterobacter tabaci, Kocuria palustris,
Kocuria rhizophila, Micrococcus aloeverae, Pseudomonas aeruginosa, Pseudomonas alcaligenes and Staphylococcus hominis subsp. hominis were mentioned in table 9.

\begin{tabular}{|c|l|l|l|}
\hline \multicolumn{2}{|l|}{ Table 9. 16S rRNA gene sequencing of Rajapur-Unhale water sample } \\
\hline S.No & Strain id & 16S rRNA based identification & $\begin{array}{l}\text { Sequence } \\
\text { acession } \\
\text { numbers }\end{array}$ \\
\hline 1 & RW1 & Kocuria rhizophila & MH715213 \\
\hline 2 & RW2 & Enhydrobacter aerosaccus & MH715214 \\
\hline 3 & RW3 & Enhydrobacter aerosaccus & MH715215 \\
\hline 4 & RW4 & Micrococcus aloeverae & MH715216 \\
\hline 5 & RW5 & Kocuria palustris & MH715217 \\
\hline 6 & RW6 & Kocuria rhizophila & MH715218 \\
\hline 7 & RW7 & Pseudomonas aeruginosa & MH715219 \\
\hline 8 & RW8 & Staphylococcus hominis subsp. hominis & MH715220 \\
\hline 9 & RW9 & Enhydrobacter aerosaccus & MH715221 \\
\hline 10 & RW10 & Elstera litoralis & MH715222 \\
\hline 11 & RW12 & Bacillus subtilis subsp. inaquosorum & MH715223 \\
\hline 12 & RW13 & Kocuria rhizophila & MH715224 \\
\hline 13 & RW14 & Bacillus tequilensis & MH715225 \\
\hline 14 & RW17 & Enterobacter tabaci & MH715226 \\
\hline 15 & RW18 & Pseudomonas alcaligenes & MH715227 \\
\hline
\end{tabular}

The total diversity of bacterial isolates from sediments and water sample were identified through molecular approach in which the diversity and abundance found to be extreme in Rajapur-Unhale sediment sample compared to Rajapur-Unhale water sample. This might be due to the sediments which persist there in hot springs for longer duration compared to water and moreover the sediments could able to provide maximum nutrients required for the growth of the bacterial isolates than water. The distribution of the isolates were identified and shown in fig. 7 . 


\section{Available online at www.ijrat.org}

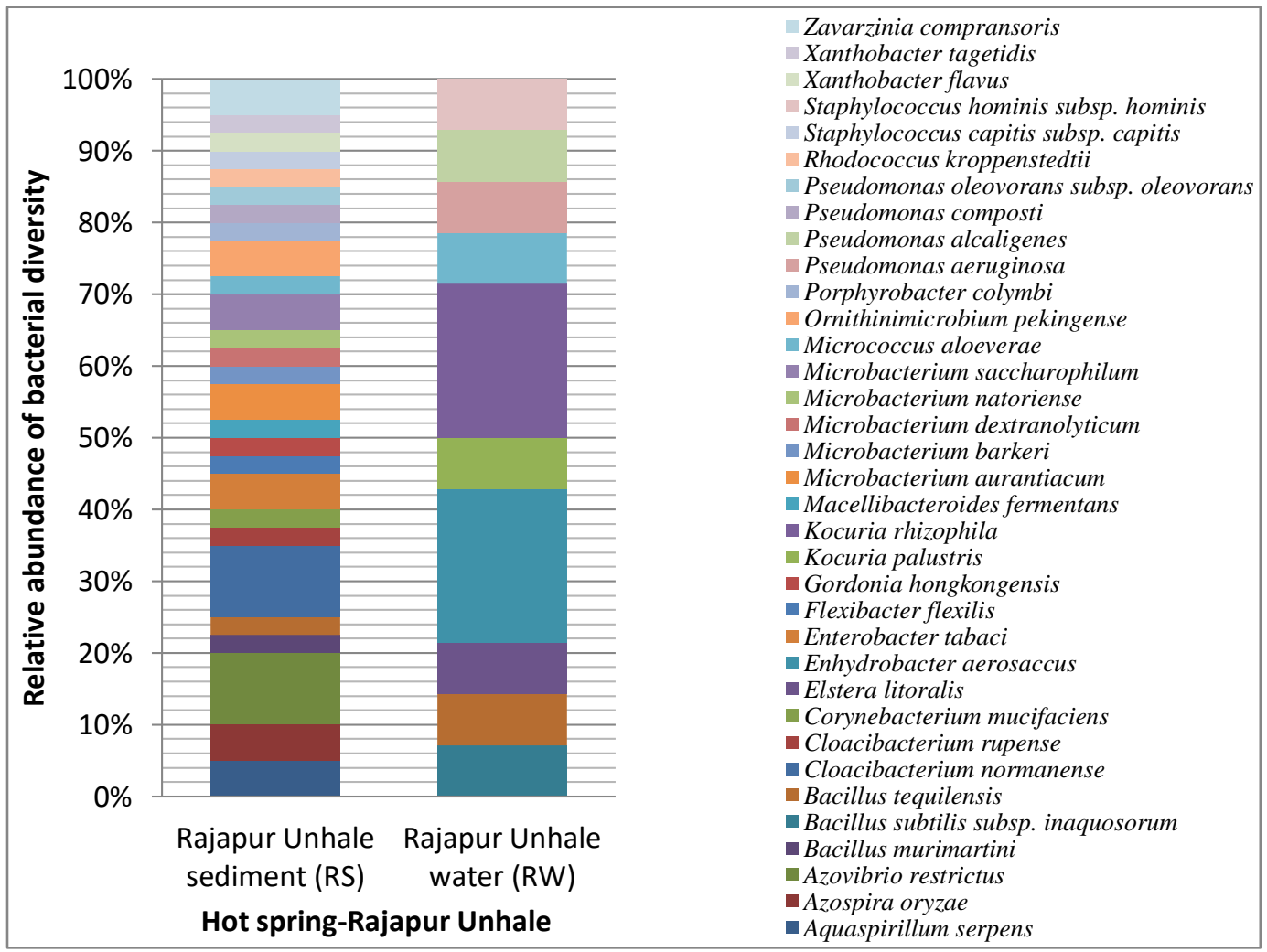

Fig.7. Percentage relative abundance of bacterial Species present in Rajapur-Unhale hot springs.

The Venny (Oliveros, 2015) an interactive tool for comparing lists with Venn's diagrams signifies the number and percentage of the identified isolates shown its similarity and uniqueness among the two samples of hot springs. In Rajapur-Unhale sediment sample, twenty four $(68.6 \%)$ isolates were found to be unique whereas, in Rajapur-unhale water sample eight $(22.9 \%)$ isolates were found to be unique which means it specifically confronts the presence of bacterial communities signifies in particular niche. Among 55 isolates three (8.6\%) isolates which were common in both Rajapur-Unhale sediment and Rajapur-unhale water samples were mentioned in fig.8.

RS

RW

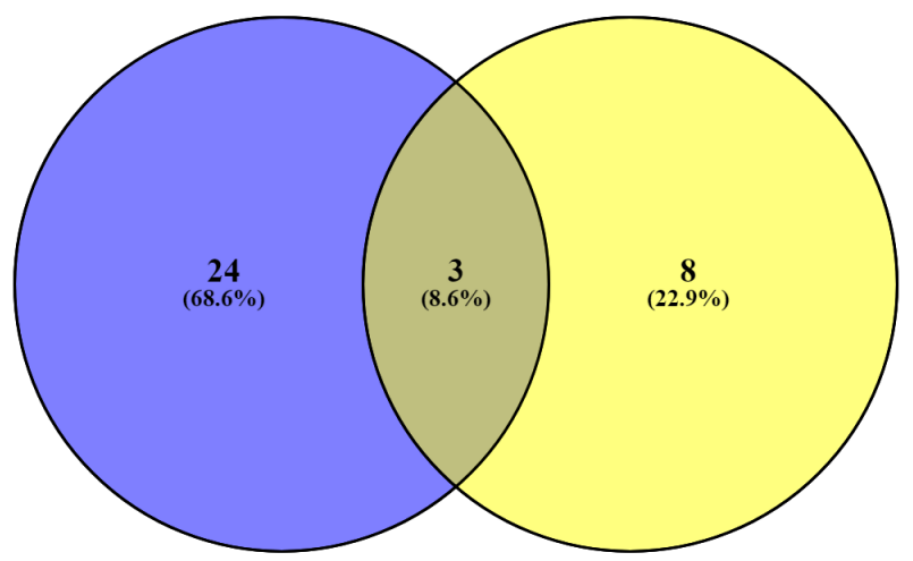

Fig.8. Number and percentage of bacterial species found in Rajapur-Unhale hot springs

3.7. Comparison Of MALDI-TOF And 16S Rrna Gene Sequencing Based Identification.

MALDI-TOF based identification was common in clinical isolates for easy detection and identification of bacterial infection of diseased patient samples. In this study we also used MALDI-TOF approach for the identification of environmental isolates to minimize the identification time and cost of 
International Journal of Research in Advent Technology, Vol.7, No.4, April 2019

E-ISSN: 2321-9637

Available online at www.ijrat.org

sequencing. 16S rRNA gene sequencing found to be gold standard for the identification of bacterial isolates from all the niches (Janda and Abbott, 2007). In comparison the MALDI-TOF could identify only 15 isolates among 55 isolates obtained from this study. Out of 15 isolates identified the isolates RS2, RS19, RS22, RW5, RW8, RW12 and RW18 were identified correctly in both genus and species level. The isolates RS9, RS53, RW7 and RW17 were identified genus level similar to $16 \mathrm{~S}$ rRNA gene sequencing. The isolates RS7, RS23, RS41 and RW9 were found to be mismatched identification compared to $16 \mathrm{~S}$ identification were mentioned in table 10. Thus, the isolates were identified in $16 \mathrm{~S}$ were considered to be the best method for the identification of bacterial isolates. Since sequencing remains strenuous and time consuming, more rapidly identification systems have been developed designed for medical purposes. All identification methods depend on the quality of the fundamental database, and achieve very well on bacteria studied from a medical application background (Xiao et al. 2014). The MALDI-TOF database needs to be modernized with environmental isolates for easy identification and cost effective identification.

\begin{tabular}{|c|c|c|c|c|}
\hline S.No & Strain id & $\begin{array}{l}\text { MALDI-TOF } \\
\text { identification }\end{array}$ & 16S rRNA based identification & $\begin{array}{l}\text { Sequence } \\
\text { acession } \\
\text { numbers }\end{array}$ \\
\hline 41 & RS1 & Not reliable identification & Cloacibacterium normanense & MH715173 \\
\hline 42 & RS2 & $\begin{array}{l}\text { Corynebacterium } \\
\text { mucifaciens }\end{array}$ & Corynebacterium mucifaciens & MH715174 \\
\hline 43 & RS3 & Not reliable identification & Azovibrio restrictus & MH715175 \\
\hline 44 & RS4 & Not reliable identification & Microbacterium dextranolyticum & MH715176 \\
\hline 45 & RS5 & Not reliable identification & Flexibacter flexilis & MH715177 \\
\hline 46 & RS6 & Not reliable identification & Aquaspirillum serpens & MH715178 \\
\hline 47 & RS8 & Not reliable identification & Microbacterium aurantiacum & MH715179 \\
\hline 48 & RS9 & Enterobacter kobei & Enterobacter tabaci & MH715180 \\
\hline 49 & RS10 & Not reliable identification & Cloacibacterium normanense & MH715181 \\
\hline 50 & RS17 & Escherichia coli & Cloacibacterium normanense & MH715182 \\
\hline 51 & RS19 & Staphylococcus capitis & Staphylococcus capitis subsp. capitis & MH715183 \\
\hline 52 & RS22 & Pseudomonas oleovorans & $\begin{array}{l}\text { Pseudomonas oleovorans } \\
\text { oleovorans }\end{array}$ & MH715184 \\
\hline 53 & RS23 & Micrococcus luteus & Bacillus murimartini & MH715185 \\
\hline 54 & RS26 & Not reliable identification & Azospira oryzae & MH715186 \\
\hline 55 & RS33 & Not reliable identification & Azospira oryzae & MH715187 \\
\hline 56 & RS34 & Not reliable identification & Enterobacter tabaci & MH715188 \\
\hline 57 & RS36 & Not reliable identification & Azovibrio restrictus & MH715189 \\
\hline 58 & RS37 & Not reliable identification & Micrococcus aloeverae & MH715190 \\
\hline 59 & RS38 & Not reliable identification & Porphyrobacter colymbi & MH715191 \\
\hline 60 & RS39 & Not reliable identification & Zavarzinia compransoris & MH715192 \\
\hline 61 & RS40 & Not reliable identification & Aquaspirillum serpens & MH715193 \\
\hline 62 & RS41 & Pseudomonas alcaligenes & Microbacterium barkeri & MH715194 \\
\hline 63 & RS42 & Not reliable identification & Ornithinimicrobium pekingense & MH715195 \\
\hline 64 & RS43 & Not reliable identification & Ornithinimicrobium pekingense & MH715196 \\
\hline 65 & RS44 & Not reliable identification & Rhodococcus kroppenstedtii & MH715197 \\
\hline 66 & RS46 & Not reliable identification & Gordonia hongkongensis & MH715198 \\
\hline 67 & RS47 & Not reliable identification & Microbacterium aurantiacum & MH715199 \\
\hline 68 & RS48 & Not reliable identification & Zavarzinia compransoris & MH715200 \\
\hline 69 & RS51 & Not reliable identification & Cloacibacterium normanense & MH715201 \\
\hline 70 & RS53 & Bacillus subtilis & Bacillus tequilensis & MH715202 \\
\hline 71 & RS54 & Not reliable identification & Macellibacteroides fermentans & MH715203 \\
\hline 72 & RS55 & Not reliable identification & Cloacibacterium rupense & MH715204 \\
\hline 73 & RS56 & Not reliable identification & Azovibrio restrictus & MH715205 \\
\hline 74 & RS57 & Not reliable identification & Microbacterium natoriense & MH715206 \\
\hline
\end{tabular}


International Journal of Research in Advent Technology, Vol.7, No.4, April 2019

E-ISSN: 2321-9637

Available online at www.ijrat.org

\begin{tabular}{|l|l|l|l|l|}
\hline 75 & RS58 & Not reliable identification & Microbacterium saccharophilum & MH715207 \\
\hline 76 & RS59 & Not reliable identification & Microbacterium saccharophilum & MH715208 \\
\hline 77 & RS60 & Not reliable identification & Xanthobacter flavus & MH715209 \\
\hline 78 & RS61 & Not reliable identification & Xanthobacter tagetidis & MH715210 \\
\hline 79 & RS62 & Not reliable identification & Azovibrio restrictus & MH715211 \\
\hline 80 & RS63 & Not reliable identification & Pseudomonas composti & MH715212 \\
\hline 81 & RW1 & Not reliable identification & Kocuria rhizophila & MH715213 \\
\hline 82 & RW2 & Not reliable identification & Enhydrobacter aerosaccus & MH715214 \\
\hline 83 & RW3 & Not reliable identification & Enhydrobacter aerosaccus & MH715215 \\
\hline 84 & RW4 & Not reliable identification & Micrococcus aloeverae & MH715216 \\
\hline 85 & RW5 & Kocuria palustris & Kocuria palustris & MH715217 \\
\hline 86 & RW6 & Not reliable identification & Kocuria rhizophila & MH715218 \\
\hline 87 & RW7 & Pseudomonas alcaligenes & Pseudomonas aeruginosa & MH715219 \\
\hline 88 & RW8 & Staphylococcus hominis & Staphylococcus hominis subsp. hominis & MH715220 \\
\hline 89 & RW9 & $\begin{array}{l}\text { Moraxella_sg_Moraxella } \\
\text { osloensis }\end{array}$ & Enhydrobacter aerosaccus & MH715221 \\
\hline 90 & RW10 & Not reliable identification & Elstera litoralis & MH715222 \\
\hline 91 & RW12 & Bacillus subtilis & Bacillus subtilis subsp. inaquosorum & MH715223 \\
\hline 92 & RW13 & Not reliable identification & Kocuria rhizophila & MH715224 \\
\hline 93 & RW14 & Not reliable identification & Bacillus tequilensis & MH715225 \\
\hline 94 & RW17 & Enterobacter hormaechei & Enterobacter tabaci & MH715226 \\
\hline 95 & RW18 & Pseudomonas alcaligenes & Pseudomonas alcaligenes & MH715227 \\
\hline
\end{tabular}

\section{CONCLUSION}

The bacterial diversity and abundance among Rajapur- Unhale sediment and water samples were identified through MALDI-TOF based identification and 16S rRNA gene sequencing based identification. In sediment sample the diversity were found to be maximum compared to water sample. Among 55 isolates obtained only 15 isolates were identified through MALDI-TOF out of which 7 isolates were identified in both genus and species level. Whereas, four isolates were identified in genus level and four isolates were found to be mismatched identification compared to $16 \mathrm{~S}$ rRNA gene sequencing. The MALDI-TOF database needs to be updated with environmental isolates for the easy and convenient identification. 16S rRNA gene sequencing found to be the gold standard method for the identification of bacterial isolates from all kinds of niche.

\section{ACKNOWLEDGEMENT}

The authors are very thankful to the Department of Microbiology, Bharathidasan University Constituent College, Kurumbalur, Perambalur, TamilNadu., India for prviding the facility to conduct our experiments and NCMR, Pune., India for helping us to perform sequencing of the samples.

\section{CONFLICT OF INTEREST}

Authors declare no conflict of interest

\section{REFERENCES}

[1] Felsenstein, J. (1981) Evolutionary Trees from dna Sequences: A Maximum Likelihood Approach. Journal of Molecular Evolution, $\quad 17, \quad 368-376$. http://dx.doi.org/10.1007/BF01734359.

[2] Felsenstein, J. (1985). Confidence limits on phylogenies: An approach using the bootstrap. Evolution 39:783-791.

[3] Janda, J.M and Abbott, S.L. (2007) 16S rRNA gene sequencing for bacterial identification in the diagnostic laboratory: pluses, perils, and pitfalls. J Clin Microbiol 45, 2761-2764.

[4] Kim, O. S., Cho, Y. J., Lee, K., Yoon, S. H., Kim, M., Na, H., Park, S. C., Jeon, Y. S., Lee, J. H. \& other authors (2012). Introducing EzTaxon-e: a prokaryotic $16 \mathrm{~S}$ rRNA gene sequence database with phylotypes that represent uncultured species. Int J Syst Evol Microbiol 62, 716-721.

[5] Kumar, R. M., Kaur, G., Kumar, A., Bala, M., Singh, N. K., Kaur, N., Kumar N.S. and Mayilraj, S. (2015). Taxonomic description and genome sequence of Bacillus campisalis sp. nov., a member of the genus bacillus isolated from solar saltern, International Journal of Systematic and Evolutionary Microbiology. 65: 3235-3240. 


\section{Available online at www.ijrat.org}

[6] Mayilraj, S., Saha, P., Suresh, K. \& Saini, H. S. (2006). Ornithinimicrobium kibberense sp. nov., isolated from the Indian Himalayas. Int J Syst Evol Microbiol 56, 1657-1661.

[7] Oliveros, J.C. (2007-2015) Venny. An interactive tool for comparing lists with Venn's diagrams. http://bioinfogp.cnb.csic.es/tools/venny/inde x.html.

[8] Saitou, N. and Nei M. (1987). The neighborjoining method: A new method for reconstructing phylogenetic trees. Molecular Biology and Evolution 4:406-425.

[9] Tamura, K., Stecher, G., Peterson, D., Filipski, A. \& Kumar, S. (2013). MEGA6: molecular evolutionary genetics analysis version 6.0. Mol Biol Evol 30, 2725-2729.

[10] Xiao, D., Ye, C., Zhang, H., Kan, B., Lu, J., $\mathrm{Xu}$, J., Jiang, X., Zhao, F. et al. (2014) The construction and evaluation of reference spectra for the identification of human pathogenic microorganisms by MALDITOF MS. PLoS One 9, e106312. 